\title{
The African Imagination: Postcolonial Studies, Canons, and Stigmatization
}

\author{
Harry Garuba \\ University of Cape Town
}

I n the prefatory remarks to his new book, The African Imagination, Abiola Irele traces the trajectory of his professional career from his initial location in Africa to his present base in an American university. The Africa phase of his career, he emphasizes, was marked by an awareness that he was involved in the definition and mapping of a distinctive terrain of imaginative expression and a new academic field known as African literature within the context of a local community of scholars and students mutually engaged in a cultural activity that they felt was central to the needs of an evolving national community. In relocating to the center of the Western academy in the United States, he continues, he now pursues his professional career in an environment within which this literature is marginal. Indeed, the literature is not only marginal, it is more often secondary, serving only to provide validating material for other disciplines and/or evidence for consolidating the paradigms of dominant discourses or epistemologies.

This simple narrative, familiar enough to African academics, seems to me to acquire a massive significance when we turn to the essays in this book. As we go through them, it is difficult to avoid the feeling that the essays collected here are animated by a certain passion of engagement that arises from a striving to reactivate or recapture the intellectual investment and commitment that accorded meaning and relevance to the earlier Africa phase of his professional life. Difference in location usually translates to a change in perspective, an adjustment in the direction of professional practice, critical, and research agenda that has significant implications for the African literary scholarship and pedagogy. And this has become even more worrying now that sizeable numbers of African academics write from their locations in universities in the West. Again, Irele very gingerly describes the implications of this change in his preface. "This book," he says, "will probably be ranged under the rubric of 'postcolonial studies,' but I hope this convenient label will not obscure its wider connections" (xiv). This cautious hope has often been frustrated at even turn by the "interpretive communities" and criteria associated with the canonization of African literary texts under the rubric of postcolonial studies. There is no better place to demonstrate this than in the critical history of Chinua Achebe's Things Fall Apart and it is against this background that Irele's reading of this novel in this book becomes immensely significant for the direction of African literary theory and criticism.

At the heart of The African Imagination is the essay entitled "The Crisis of Cultural Memory in Chinua Achebe's Things Fall Apart." Certainly more than any other text, this novel has come to be the seen as central to the evolving canon of African literature and, lately, of postcolonial literatures. Indeed, the innumerable critical essays on this novel and its ubiquitous presence in the curricula of different academic departments all over the 
world is evidence that with this novel, what we are dealing with is the phenomenon that Jonathan Arac describes as "hypercanonization" (778). Apart from simply being a literary text, it is made to bear the burden of providing documentary evidence for anthropological studies and sociological speculations, corralled to perform other functions in histories of colonialism and decolonization and, in general, being made the representative text of the African response to European colonialism and modernity. Being overburdened with so large a freight of functions and thus critically reconstituted as the representative countercanonical text results in an "unarticulated stigmatization" that, in this case, often delegitimizes other avenues of inquiry beyond those consecrated in the counterdiscursive agenda. According to Saleh D. Hassan:

This stigmatization operates in a number of ways, but it is always associated with the history of political contestation that adheres to those "subversive" texts, which were used to redefine the parameters of the English literary canon. The most common feature of this stigmatization is the representative role that the previously excluded texts have continued to play after they achieved inclusion in the canon. (297)

Hassan hastens to add that his use of the term is not a mark of negative moral or aesthetic judgment but should be understood as "an effect of the eventual canonization of countercanonical works [. . . ] a process that domesticates an ostensibly insurgent work and authorizes its more general and excessive pedagogical use" (298). I want to suggest in this review essay that the "unarticulated stigmatization" of Things Fall Apart operates by silencing or repressing its critique of African precolonial society and culture and concentrating solely on its affirmative, celebratory presentation and its discursive contestation with the West. In short, its critique of colonialism has become so hegemonic that it has virtually shut off inquiries into its other major preoccupation with the flaws and fault lines of traditional African culture and society.

Irele's reading of Things Fall Apart in this book represents the most detailed and sustained effort, that I am aware of, to reverse this "stigmatization" and redirect attention to what this book says to Africans about African culture and society. Irele does this by premising his analysis of the novel with two powerful claims that strike at the very foundations of the postcolonial canonization of literary texts. His first claim is that "the narrative voice adopted by Achebe [.. .] speaks often, perhaps even primarily, from the margins of the traditional culture" (118) and that "Achebe can be said to have undertaken the writing of Things Fall Apart out of an awareness of a primary disconnection from the indigenous background" (119). And the second is that there is "a disjunction in the novel between its overt ideological statement [and] its dispassionate and even uncompromising focus on an African community in its moment of historical crisis" (117). Since, in critical commentaries on the novel, the focus has often been on the ideological part of this twin concern, Irele insists that "the moral significance of the work seems to me to outweigh the ideological burden that has so often been laid upon it" (117). 
On the evidence of the text itself these claims may not appear as extraordinary as I have made them out to be. But when we place them against the background of some of the premises of nationalist discourse and the practices of postcolonial canonization, their significance becomes clearer. With regard to the first claim of "disconnectedness," we must recall that one of the premises of anticolonial nationalism was the native's "insider" status and the authority of his or her "connectedness" at a primary experiential level to the culture of the people. To so openly insist on a primary disconnectedness is to question this received wisdom at it roots by casting doubt on the unassailability of the native experience and thus its cultural and interpretive authority. On the heels of this questioning lurks the suspicion that once we accept this, we may be confronted with an even less palatable fact about the postcolonial canon. For, as John Guillory says, "it is precisely the fit between an author's social identity and his or her experience that is seen to determine canonical or noncanonical status" (10) in the rhetoric of canon revision. And, if Guillory is right, neither disconnection nor speaking primary from the "margins of the traditional culture" will be a great qualification. And pressing the moral claims of the novel ahead of the ideological refocuses attention on the cultural universe of the community in focus rather than its relationship with the imperializing colonial culture.

I must hasten to add here that the thrust of Irele's argument in this essay is not the qualification or appropriateness of the inclusion of this novel in the canon, even though he believes, as many other critics do, that Achebe's other novel of traditional society, Arrow of God, is a more accomplished work. His concern is with its moral significance as a text that also critiques precolonial African society. And this is the claim that motivates the essay. In pursuing this argument, Irele does not entirely strip the novel of its ideological significance; indeed, he spends a lot of time and space in underscoring this. However, he insists that, beyond being merely a character in a novel, Okonkwo is "a representative figure of African historicity" (120) and thus needs to be more seriously studied beyond simply being read as a counterdiscursive foil to colonialist myths of Africa.

In this effort, Irele implies, history rather than ethnography should be our guide. I make this distinction seriously and not simply as a sneaky reference to Christopher Miller's claims on behalf of anthropology. In Irele's own words:

It is this deep intuition of history that [. . .] distinguishes Achebe's work from that of every other African writer. This distinction emerges clearly when we contrast the tone of Things Fall Apart with that of Francophone African writings roughly contemporaneous with it, especially the works of Camara Laye, Leopold Senghor, and Cheikh Hamidou Kane, all of whom have created in obedience to a paradigm of the self that privileges the ideal of wholeness. (150)

In the analysis that follows, he focuses on Achebe's own critique of an African, specifically Igbo, precolonial culture in its social and historical constitution. He dwells on the processes of subject formation and subjectivity authorized by that culture, its internal contradictions and the crisis 
that overtakes it in its encounter with modernity and its confrontation with colonialism. Irele's close reading of the text and the wealth of detailed examples he provides give illuminating insights into hitherto unacknowledged areas of the novel. The elegiac tone that clings to the novel, especially in its depiction of cultural traditions under threat, is not motivated by an anthropological sense of "ethnographic salvage" (Clifford 112-13) in the face of dying customs and traditions. On the contrary, Irele concludes in this essay, it is "ultimately, the opening of the African consciousness to the possibility of its transcendence, to the historical chance of a new collective being and existential project" (152).

The focus on Africa in and for itself rather than its relational positioning with reference to Eurocentric discourses, the centralization of the moral rather than the ideological question, and the rigor of analysis is what makes this essay such a significant effort at redirecting the attention of African literary critics from what Neil Lazarus describes as "the fetish of 'the West' in postcolonial theory." The argument Irele makes may appear heretical to the "postcolonial" agenda as such or its reductive variant, but it is the "heresy" of readings of this kind that prevent stigmatized texts from asphyxiation by giving them a breathe of fresh air.

Speaking of aerating spaces, one of the recurrent complaints that those of us who have to guide students into the domains of contemporary literature and theory encounter again and again is that a forbidding jargon has usurped the authority of the narratives we claim are the objects of our critical attention. It is difficult, in these circumstances, not to commend the lucid, lyrical prose of Irele's book. As Biodun Jeyifo notes in the blurb, the author writes "with a full command of the most current idioms and protocols of critical theory and cultural criticism but does so with the elegance, clarity, and gravity that are often lacking in the intellectual climate of postmodernism." Not only does the uncluttered language of the book make it an inviting read, the gravity he brings to his analyses of trends and texts subverts the often facile oppositions which reductive ideological criticism routinely provides.

It is interesting in this regard to note that while Irele asserts that orality "stands as the fundamental reference of discourse and the imaginative mode in Africa" (11), he also insists that

[t] radition is no longer accepted as a given of African consciousness, girding us with the force of evidence and essentialism so that we can oppose the cooptation of our minds and sensibilities by the discourse of Europe. Tradition has become problematic in a strictly philosophical sense; it has come to be deprived of its axiomatic and normative significance and has been made answerable, therefore, to a new effort of redefinition. It has thus become the subject of a lively and even intense controversy, calling forth various and contradictory responses. (62)

This kind of nuanced reading that refuses to trade in simplifications and the suppression of "unsavory" details of the African experience is-as I suggested earlier - a result of his effort to reactivate the commitment that char- 
acterized his earlier location in Africa and thus position his work within the complex realities of contemporary Africa rather than in relation to some exoticist, essentializing discourses generated from the West.

The African Imagination begins with critical and conceptual surveys of the field in such chapters as "The African Imagination," "Orality, Literacy and African Literature," "African Letters: The Making of a Tradition," and "Dimensions of African Discourse"-chapters that explore the major issues and debates that have defined modern African literature. The expansive scope of the titles of the chapters is an indication of the broad sweep of the arguments on the key issues of language, orality, authenticity, and the tradition of African writing. These chapters dovetail into others that concentrate on individual authors, prominent among whom are the francophone Amadou Hampaté Bâ and Ahmadou Korouma and the anglophone Chinua Achebe and J. P. Clark-Bekederemo. The individual studies take on the two major linguistic traditions of modern African writing in the European languages. Irele also devotes a chapter to the work of the West Indian poet Edward Kamau Braithwaite, exploring through his poem Masks the significance of Africa to the Caribbean imagination. A final chapter, "Parables of the African Condition: The New Realism in African Fiction," looks at the works of a group of new writers from Africa whose writing engage directly with the condition of contemporary Africa.

For those whose cherished the groundbreaking work done in Irele's earlier book, The African Experience in Literature and Ideology, this new book will be especially welcome because it shows that even though the critic may have emigrated, his research and critical agenda have not been fundamentally reconstituted in the direction of the West.

\section{WORKS CITED}

Arac, Jonathan. "Why Does One Care about the Aesthetic Value of Huckleberry Finn?" New Literary History 30 (1999): 769-84.

Clifford, J. "On Ethnographic Allegory.” Writing Culture: The Poetics and Politics of Ethnography. Ed. J. Clifford and G. Marcus. Berkeley: U of California P, 1986. 98-121.

Guillory, John. Cultural Capital: The Problem of Literary Canon Formation. Chicago: U of Chicago P, 1993.

Hassan, Saleh D. "Canons after 'Postcolonial Studies'” Pedagogy:Critical Approaches to Teaching Literature, Language, Composition, and Culture 1.2 (2000): 297-304.

Irele, Abiola. The African Experience in Literature and Ideology. London: Heinemann Educational, 1981.

- The African Imagination: Literature in Africa and the Black Diaspora. Oxford: Oxford UP, 2001.

Lazarus, Neil. "The Fetish of 'the West' in Postcolonial Theory." Marxism, Modernity, and Postcolonial Studies. Ed. Crystal Bartolovich and Neil Lazarus. Cambridge: Cambridge UP, 2002. 43-64. 
Copyright $\odot 2003$ EBSCO Publishing 